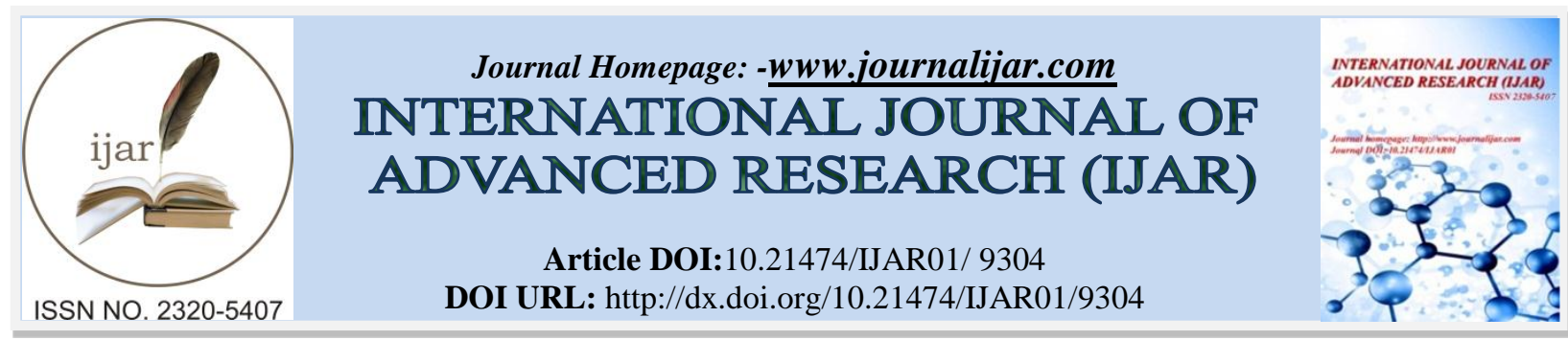

RESEARCH ARTICLE

\title{
OPTIMIZATION BY FULL FACTORIAL DESIGN OF LEAD ADSORPTION CONDITIONS ON ACTIVATED CARBONS FROM COCONUT SHELLS.
}

\section{Kouassi Narcisse Aboua ${ }^{1}$, Kossonou Roland N'Guettia ${ }^{2}$, Moussa Diarra ${ }^{3}$, Kouadio Dibi ${ }^{1}$, Donafologo Baba} Soro $^{1}$, Ladji Méité ${ }^{1}$, Mamadou Koné ${ }^{1}$ and Karim Sory Traoré ${ }^{1}$.

1. Université Nangui Abrogoua, Unité de Formation et de Recherche Sciences et Gestion de l'Environnement, Laboratoire des Sciences de l'Environnement, 02 BP 801 Abidjan 02, Côte d'Ivoire.

2. Laboratoire National d'Appui au Développement Agricole (LANADA), 04 BP 612 Abidjan 04, Côte d'Ivoire.

3. Université Jean Lorougnon GUEDE, Unité de Formation et de Recherche Environnement, Laboratoire des Sciences et Technologie de l'Environnement, BP 150 Daloa, Côte d'Ivoire.

\section{Manuscript Info}

Manuscript History

Received: 15 April 2019

Final Accepted: 17 May 2019

Published: June 2019

Key words:-

ACTIVATED CARBON, ADSORPTION, LEAD, OPTIMIZATION, EXPERIMENTAL DESIGN, WASTEWATER.

\begin{abstract}
Adsorption of heavy metals on activated carbons is influenced by various factors that must be controlled. This study investigates the optimal conditions for removal lead on activated carbon using experimental designs. Thus, influence of three parameters $(\mathrm{pH}$, lead concentration and activated carbon) on adsorption rate was studied. Activated carbons was prepared from coconuts shells of Côte d'Ivoire by using chemical activation method. $\mathrm{pH}$, lead concentration and coal nature are the factors considered in the two-level complete factorial plan used for optimization. values of lead elimination rate are between $87 \%$ and $96 \%$ thus indicating pertinence of choice of the experimental domain. Moreover, two of the three factors; $\mathrm{pH}$ and lead concentration have a significant influence on the lead removal rate. Also, interactions between carbon type and lead concentration and those between $\mathrm{pH}$ and concentration have a significant influence on adsorption. Thus, the optimal adsorption conditions of $50 \mathrm{~mL}$ of lead at $150 \mathrm{mg} / \mathrm{L}$ of concentration are obtained with $0.3 \mathrm{~g}$ of activated carbon, at $\mathrm{pH} 6$ and at a temperature of $25^{\circ} \mathrm{C}$. Experimental designs therefore make it possible to optimize lead removal conditions from wastewater.
\end{abstract}

Copy Right, IJAR, 2019,. All rights reserved.

\section{Introduction:-}

Water pollution by heavy metals is a source of environmental degradation and is of interest internationally (Demim et al. 2013). Lead is one of the most toxic heavy metals, it is found most often in environmental compartments in the form of traces. Its presence in wastewater is due to its use in many industrial processes such as production of paint, dyes, glass, fuel and batteries. This pollutant can concentrate along the food chain and accumulate in certain organs of the human body including central nervous system, kidneys and hematopoietic system (Song et al., 2010). Removal of $\left(\mathrm{Pb}_{2}{ }^{+}\right)$ions from wastewater can be achieved by processes such as chemical precipitation, ion exchange, reverse osmosis and activated carbon adsorption (Yobouet et al., 2018). Among these methods, activated carbon adsorption is the most efficient and economical technique for the removal of lead (Gbamele et al., 2016; Murat et al., 2018). Moreover, adsorption phenomena are controlled by adsorption parameters such as nature of the activated

Corresponding Author:-Kouassi Narcisse aboua.

Address:-Université Nangui Abrogoua, Unité de Formation et de Recherche Sciences et Gestion de l'Environnement, Laboratoire des Sciences de l'Environnement, 02 BP 801 Abidjan 02, Côte d'Ivoire. 
carbon, effect of the mass ratio of the carbon/volume of the solution, $\mathrm{pH}$, temperature and contact time. Thus, in order to optimize the operating conditions, mathematical models are increasingly used (Tchakala et al., 2012). Optimization tools generally used are experimental designs that reduce the number of experiments to be carried out without losing on quality of the results sought. There are several types of experiment designs. But the most commonly used because simple, is the complete two-level factorial design and is noted $2^{\mathrm{k}}$ (Aboua et al., 2010). In this work, it is therefore a question of optimizing the lead elimination conditions considering nature of active carbon, $\mathrm{pH}$ of the reaction medium and initial concentration of lead. Process of removing lead is based on activated carbon adsorption synthesized from coconut shells, an abundant and cheap material in Côte d'Ivoire.

\section{Material and methods:-}

Reagents and solutions

Orthophosphoric acid (85\%), sodium hydroxide (98\%), hydrochloric acid (37\%), lead nitrate and nitric acid (98\%) are mainly the chemicals used. They are of analytical quality and are provided by Prolabo, Suvchem, Panreac Quimica S.A.U.

Coconut shells, precursors of activated carbon, come from agricultural waste in Côte d'Ivoire.

The synthetic lead solutions used in the various tests were obtained by dissolving the lead nitrate in distilled water. The main physico-chemical characteristics of lead are given in Table I.

Table 1:-Physico-chemical characteristics of lead (Me Convey et al., 1985; Mazet et al., 1990).

\begin{tabular}{|l|l|}
\hline Atomic number & 82 \\
\hline Atomic mass & $207,2 \pm 0,1 \mathrm{u}$ \\
\hline Density & $11,44 \mathrm{~g} . \mathrm{cm}^{-3}$ à $20{ }^{\circ} \mathrm{C}$ \\
\hline Melting temperature & $260{ }^{\circ} \mathrm{C}$ \\
\hline Boiling temperature & $1755^{\circ} \mathrm{C}$ \\
\hline Electronegativity of Pauling & 1,8 \\
\hline Atomic radius (Van der Waals) & $0,154 \mathrm{~nm}$ \\
\hline Ionic radius & $0,132 \mathrm{~nm}(+\mathrm{II}) ; 0,084 \mathrm{~nm}(+\mathrm{IV})$ \\
\hline
\end{tabular}

\subsection{Preparation of activated carbons}

Activated carbons were prepared by chemical activation with orthophosphoric acid $30 \%$ according to the method described below.

Coconut shells $(300 \mathrm{~g})$ having undergone pretreatment removing the impurities are impregnated in $300 \mathrm{~mL}$ of a solution of orthophosphoric acid $30 \%$ for $24 \mathrm{~h}$. After 24 hours, the impregnated samples are dried in an oven at $110^{\circ} \mathrm{C}$ until complete evaporation of the impregnating liquid. Dried samples are placed in crucibles and carried in an oven to be carbonized respectively at different temperatures $400^{\circ} \mathrm{C}$ and $600^{\circ} \mathrm{C}$ for three (3) hours. The charred samples are washed with distilled water while stirring until the $\mathrm{pH}$ of the rinsing water is between 6.5 and 7 . These samples are finally dried in an oven at $110{ }^{\circ} \mathrm{C}$ for 24 hours and packaged in ready-to-use glass jars.

\subsection{Characterization of coals}

Different parameters were determined on the carbons obtained to understand their behavior during lead adsorption tests.

\subsubsection{Ash rate}

A mass of $5 \mathrm{~g}$ of activated carbon dried in an oven at $110^{\circ} \mathrm{C}$ until stabilization of the mass of dry matter and placed in crucibles. Samples are then baked at $500^{\circ} \mathrm{C}$ for 8 hours. These crucibles are finally weighed after being cooled. calculation of the ash rate (TC) is as follows:

$$
\operatorname{TC}(\%)=\frac{m_{2}-m_{0}}{m_{1}-m_{0}} \times 100
$$

$\mathrm{m}_{0}$ : mass of the empty crucible

$\mathrm{m}_{1}$ : crucible mass + oven-dried sample at $110^{\circ} \mathrm{C}$

$\mathrm{m}_{2}$ : mass of the crucible + calcined residue 


\subsubsection{Humidity rate}

Moisture content $(\mathrm{TH})$ is a ratio expressed as a percentage; it is determined by the drying of the adsorbent in an oven. $5 \mathrm{~g}$ of activated carbon are placed in a crucible. It is then dried in an oven at $110^{\circ} \mathrm{C}$. for 24 hours. After 24 hours, the crucible is removed from the oven and weighed to determine the moisture content. The following equation is used to determine the moisture content.

$$
T H(\%)=\frac{m_{1}-m_{2}}{m_{1}} \times 100
$$

$\mathrm{m}_{1}$ : mass of activated carbon before drying at $110^{\circ} \mathrm{C}$

$\mathrm{m}_{2}$ : mass of carbon dried at $110^{\circ} \mathrm{C}$ for 24 hours

\subsubsection{Iodine number}

Iodine number, expressed in $\mathrm{mg} / \mathrm{g}$, is the quantity of iodine adsorbed per gram of activated carbon in an aqueous solution of iodine $\mathrm{I}_{2}$ of normality $0.02 \mathrm{~N}$. It characterizes the accessible zones any particle smaller than or equal to that of the iodine molecule (Gueye, 2015). To determine the iodine value, we used a method that is an adaptation of the 1989 CEFIC method and AWWA B600-78 (Mazet et al., 2017).

In a $100 \mathrm{ml}$ beaker, about $\mathrm{m}=0.2 \mathrm{~g}$ of previously dried carbonic weighed in an oven at $110^{\circ} \mathrm{C}$. for 24 hours. $20 \mathrm{ml}$ of the $0.02 \mathrm{~N}$ iodine solution are pipetted and stirred for 4-5 minutes. The mixture is filtered on ash less filter paper and $10 \mathrm{ml}$ of the filtrate is taken and placed in an erlenmeyer flask. From the burette, sodium thiosulphate is poured into the erlenmeyer flask containing the filtrate in the presence of starch until the solution is completely bleached. $\mathrm{V}_{\text {thio }}$ is the volume in $\mathrm{mL}$ of thiosulfate equivalence. The iodine number expressed in $\mathrm{mg} / \mathrm{g}$ is given by the following relation:

$$
\mathrm{Q}_{\mathrm{I} 2}=\frac{C_{0} \times C_{t h} \times V_{t h}}{2 V_{I 2}} \times \frac{M_{I 2} \times V_{a d s}}{m_{C A}}
$$

$\mathrm{C}_{0}$ : concentration of the initial solution of iodine ( $\left.\mathrm{L}\right)$

$\mathrm{C}_{\mathrm{th}}$ : concentration of sodium thiosulfate $(\mathrm{mol} / \mathrm{L})$

Vth: volume of sodium thiosulfate poured (L)

$\mathrm{V}_{\mathrm{I} 2}$ : volume of the measured solution $(\mathrm{L})$

$\mathrm{M}_{\mathrm{I} 2}$ : molar mass of iodine $(\mathrm{g} / \mathrm{mol})$

$\mathrm{V}_{\text {ads }}$ : adsorption volume $(\mathrm{L})$

$\mathrm{m}_{\mathrm{CA}}:$ mass of activated carbon $(\mathrm{g})$

\subsubsection{Specific surface}

Specific surface of the prepared carbons is determined according to the adsorption method of the acetic acid molecule developed by (Avon et al., 2001). In Erlenmeyer flasks, a mass of $1 \mathrm{~g}$ of carbon and a volume of about 50 $\mathrm{ml}$ of acetic acid of known concentration ranging from 0.015 to 0.15 mol are placed. $\mathrm{L}^{-1}$ is added. These erlenmeyer flasks are then closed and placed in a thermostat bath set at the appropriate temperature and stirred regularly for thirty minutes (30 minutes). The mixture is left to stand during an hour before being filtered. After filtration, a volume of 5 or $10 \mathrm{ml}$ of solute is titrated with a $0.1 \mathrm{~mol}^{-1}$ solution of sodium hydroxide.

The amount of solute adsorbed per liter of solution is determined by the difference between the initial concentration (Ci) and the equilibrium concentration (Ce), then the amount of acetic acid adsorbed at equilibrium is deduced according to the following relationship:

$$
Q e=\frac{\mathrm{Ce}-\mathrm{Ci}}{\mathrm{m}}
$$

Qe: amount of acetic acid adsorbed at equilibrium (mol/g)

Ce: equilibrium concentration of acetic acid (mol/L)

Ci: initial concentration of acetic acid $(\mathrm{mol} / \mathrm{L})$

$\mathrm{m}$ : mass of activated carbon $(\mathrm{g})$

For the determination of the specific surface area SL $\left(\mathrm{m}^{2} / \mathrm{g}\right)$, the Langmuir equation is written in the form: 


$$
\frac{C_{e}}{q_{e}}=\frac{1}{q_{m} b}+\frac{C_{e}}{q_{m}}
$$

$\mathrm{C}_{\mathrm{e}}$ : Concentration of acetic acid solution at equilibrium (in mol /L)

qe: Amount of acetic acid equilibrated with carbon (in $\mathrm{mol} / \mathrm{g}$ )

qm: Maximum saturation capacity of the carbon (in mol $/ \mathrm{g}$ )

b: Thermodynamic constant of the adsorption equilibrium (in L/mol)

$\mathrm{qm}$ : Deduced from the slope of the $\frac{C_{e}}{q_{e}}$ curve as a function of Ce.

Knowledge of qm leads to the determination of the surface SL by the relation:

$$
S_{L}=q_{m} \times S \times N_{0}
$$

$\mathrm{S}=21 \AA^{2}$ is the area occupied by a molecule of acetic acid

$\mathrm{N}_{0}=6,02 \cdot 10^{23} \mathrm{~mol}^{-1}$ is the number of Avogadro.

\subsection{Experimental design}

\subsubsection{Methodology of the experimental designs}

There are different types of experimental models. The most commonly used, because of its simplicity, is the complete factorial plane, denoted $2^{\mathrm{k}}$, which is the combination of all levels (2) of all factors (k) (Feinberg, 1996; Massart et al., 1988). This method consists in using all the data simultaneously to calculate each factor. The results are processed using multiple linear regression and variance analysis. It states that the answer is a linear function of all factors. Thus, to determine this function is to find the coefficients of the following polynomial equation:

$$
Y=a_{0}+a_{1} X_{1}+a_{2} X_{2}+\ldots+a_{k} X_{k}+\ldots+a_{12} X_{1} X_{2}+\ldots+a_{k-1 k} X_{k-1} X_{k}+a_{1 \ldots k} X_{1} X_{2} \ldots X_{k}
$$

$\mathrm{a}_{\mathrm{i}}$ : Effect of the factor $\mathrm{X}_{\mathrm{i}}$

$\mathrm{a}_{\mathrm{ij}}$ : Effect of the interactions between factors $X_{\mathrm{i}}$ and $\mathrm{X}_{\mathrm{j}}$.

The determination of experimental domain, experimental designs, estimates and statistics of the polynomial coefficients is carried out using NEMRODW software (Mathieu et al., version 9901).

\subsubsection{Choice of factors}

An appropriate choice of parameter variation domains is an essential condition for establishing a precise model that perfectly describes the studied process (Choumane et al., 2016; Depci et al., 2012). Type of activated carbon, pH and initial concentration of lead were selected as parameters of the study. Lead removal rate, Y, is the measured response. Each factor $\left(\mathrm{X}_{\mathrm{i}}\right)$ at a low level and a high level denoted respectively $(-1)$ and $(+1)$ in coded variable (Table 2).

Table 2:-Experimental field

\begin{tabular}{|l|c|c|c|}
\hline Facteurs & Variable & Niveau bas $\mathbf{( - 1 )}$ & Niveau haut $\mathbf{( + 1 )}$ \\
\hline Type of activated carbon & $\mathrm{X}_{1}$ & CAT1 & CAT2 \\
\hline $\mathrm{pH}$ & $\mathrm{X}_{2}$ & 4 & 6 \\
\hline Initial concentration of lead $(\mathrm{mg} / \mathrm{L})$ & $\mathrm{X}_{3}$ & 30 & 150 \\
\hline
\end{tabular}

\subsection{Analytical technique}

Lead adsorption was performed in batches at room temperature $\left(30 \pm 2^{\circ} \mathrm{C}\right)$. For each test, a volume of $50 \mathrm{~mL}$ of synthetic solutions containing lead was used. The operating conditions for the optimization are fixed by the experimental plan. The activated carbon/metal solution mixture is stirred for a period and filtered before analysis by the Shimadzu Type AA6500 flame atomic absorption spectrometer (SAA). The quantity of lead adsorbed at equilibrium is calculated according to the expression:

$$
q_{e}=\frac{\left(C_{o}-C_{e}\right) \times V}{m}
$$

m: Mass of the sample $(\mathrm{g})$, 
$\mathrm{V}$ : Volume of the solution (L)

Co: Initial concentration of lead ( $\mathrm{mg} / \mathrm{L})$

$\mathrm{C}_{\mathrm{e}}$ : Concentration of metals at equilibrium $(\mathrm{mg} / \mathrm{L})$

qe: Amount of metals adsorbed at equilibrium ( $\mathrm{mg} / \mathrm{g}$ of adsorbent).

For determination of the lead adsorption rate $(\mathrm{T})$, the following expression is used.

$$
T(\%)=\frac{\left(C_{o}-C_{r}\right) \times 100}{C_{o}}
$$

Co: Initial concentration of lead ( $\mathrm{mg} / \mathrm{L})$

$\mathrm{Cr}$ : Residual concentration of lead (mg / L).

\section{Results:-}

\subsection{Characterization of activated carbons}

Two types of carbons CAT1 for $\mathrm{T}=400^{\circ} \mathrm{C}$ and CAT2 for $\mathrm{T}=600^{\circ} \mathrm{C}$ are obtained. Results of characterization tests for both types of carbon are shown in Table 3.

Table3:-Characterization of activated carbons

\begin{tabular}{|l|c|c|c|c|c|}
\hline Types of carbons & $\begin{array}{c}\text { Specific surface } \\
\left(\mathrm{m}^{2} / \mathrm{g}\right)\end{array}$ & $\begin{array}{c}\text { Iodine number } \\
(\mathrm{mg} / \mathrm{g})\end{array}$ & $\begin{array}{c}\text { Ash rate } \\
(\%)\end{array}$ & $\begin{array}{c}\text { Humidity level } \\
(\%)\end{array}$ & $\begin{array}{c}\text { returns } \\
(\%)\end{array}$ \\
\hline CAT1 à 400 C & 97,96 & 456,86 & 1,50 & 8,00 & 37,17 \\
\hline CAT2 à 600 C & 75,72 & 426,40 & 2,50 & 2,00 & 34,83 \\
\hline
\end{tabular}

\section{Determination of equilibrium times}

The influence of stirring time is used to determine time required to reach the adsorption equilibrium for each activated carbon. Results obtained are presented in figure1.

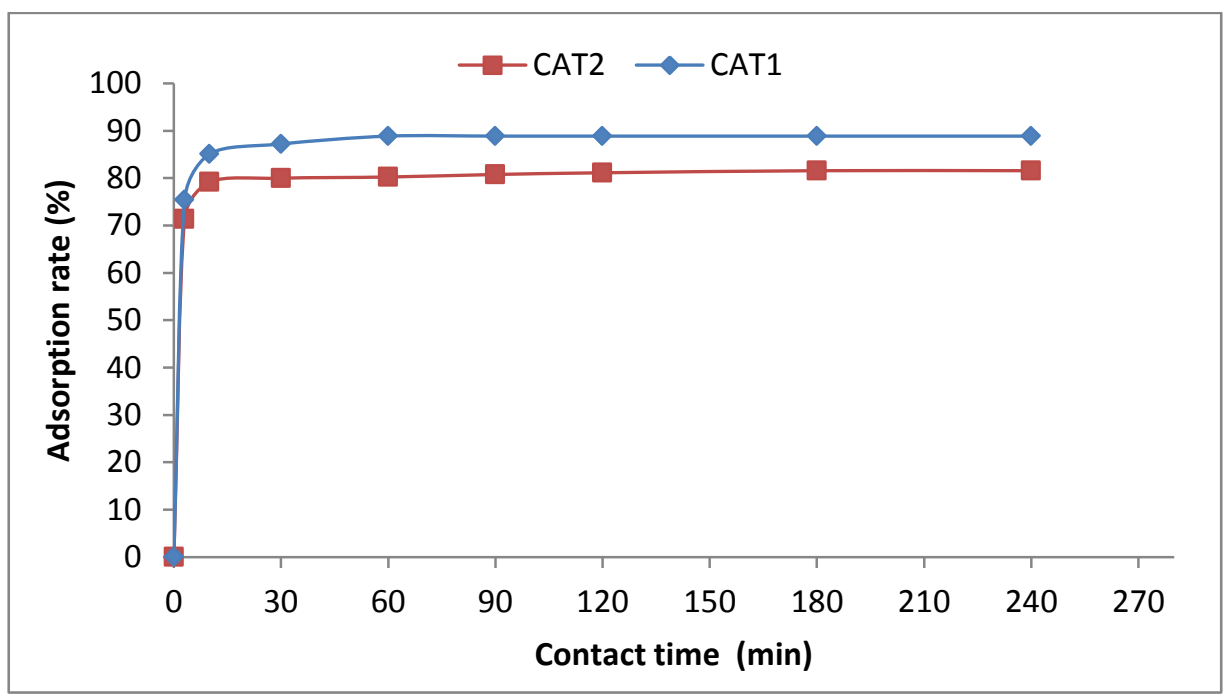

Figure 1:-Effet of contact time on lead adsorption. $\left(\mathrm{T}=25^{\circ} \mathrm{C}, \mathrm{m}=0,3 \mathrm{~g}, \mathrm{~V}=50 \mathrm{~mL}\right.$ et $\left.[\mathrm{Pb}]=30 \mathrm{mg} / \mathrm{L}\right)$

\section{Optimization of lead adsorption conditions}

\section{Experimental design and coefficient of factors}

The table 4 presents the experimental design and the experimental results for the three factors studied. 
Table 4:-Experimental design for the three factors

\begin{tabular}{|c|c|c|c|c|}
\hline $\mathbf{N}^{\circ}$ Expérience & Type of CA & $\mathbf{p H}$ & Concentration & Adsorption rate (\%) \\
\hline 1 & CAT1 & 3 & 30 & 89,78 \\
\hline 2 & CAT2 & 3 & 30 & 91,84 \\
\hline 3 & CAT1 & 6 & 30 & 89,06 \\
\hline 4 & CAT2 & 6 & 30 & 88,01 \\
\hline 5 & CAT1 & 3 & 150 & 88,91 \\
\hline 6 & CAT2 & 3 & 150 & 86,91 \\
\hline 7 & CAT1 & 6 & 150 & 96,15 \\
\hline 8 & CAT2 & 6 & 150 & 93,72 \\
\hline
\end{tabular}

This table includes the eight experimental conditions in a random order and the lead adsorption rate associated with each test

Estimation and statistics of coefficients

The table 5 presents estimate and statistics of coefficients of the polynomial (equation 7).

Table 5:-Estimation and statistics of coefficients

\begin{tabular}{|c|c|c|c|}
\hline Name & Coefficient & Ecart-Type & Signif. \% \\
\hline b0 & 90,548 & 0,335 & $0,236^{* *}$ \\
\hline b1 & $-0,428$ & 0,335 & 42,3 \\
\hline b2 & 1,188 & 0,335 & $17,5^{*}$ \\
\hline b3 & 0,875 & 0,335 & $23,3^{*}$ \\
\hline b12 & $-0,443$ & 0,335 & 41,3 \\
\hline b13 & $-0,680$ & 0,335 & $29,1^{*}$ \\
\hline b23 & 2,325 & 0,335 & $9,1^{*}$ \\
\hline
\end{tabular}

The significance test of each coefficient of the model was performed by taking the absolute value of the coefficients which must be greater than twice the standard deviation.

\subsubsection{Effects of different factors}

The importance of factor effects as well as their interactions is illustrated in Figure 2.

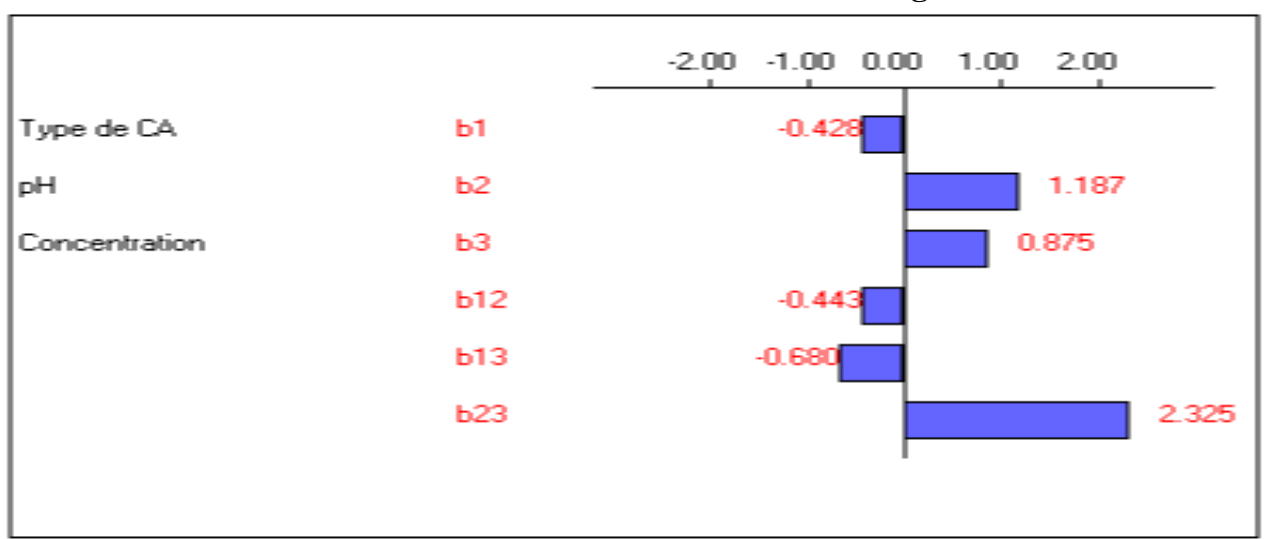

Figure 2:-Graphical study of the effects of factors on the response (adsorption rate).

Figures 3 and 4 show respectively interactions between the type of carbon and the concentration and that between the $\mathrm{pH}$ and the concentration. The values in each small square represent the combinations of the levels of the two factors. 

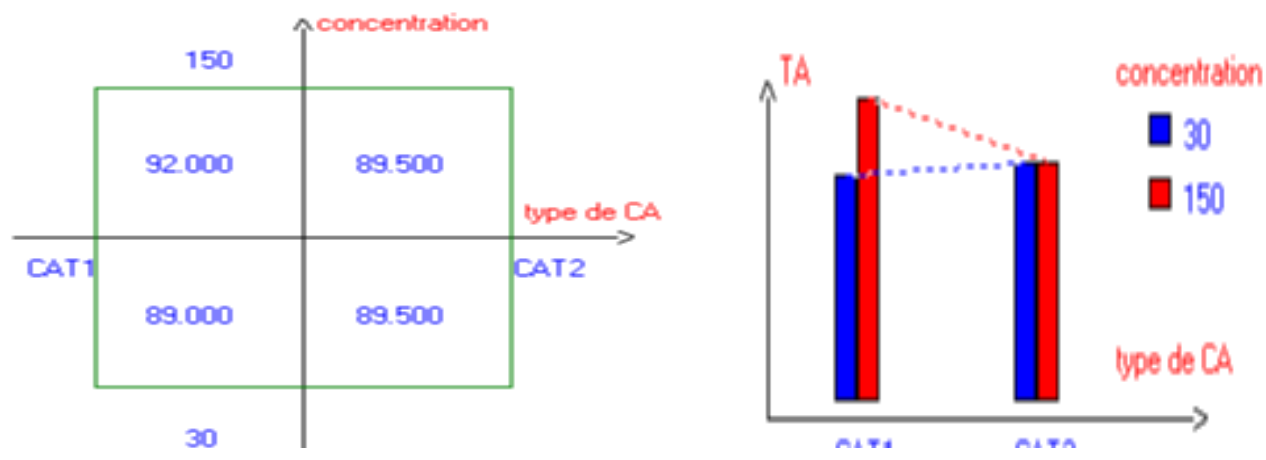

Figure 3:-Graphical Study of Typical AC Interaction / Lead Concentration
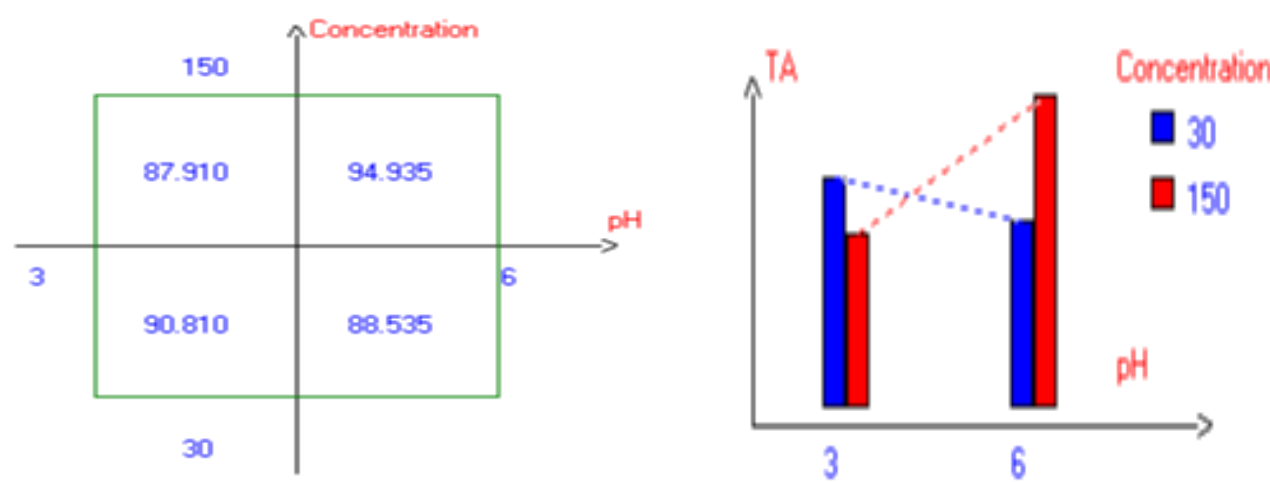

Figure 4:-Graphical study of the $\mathrm{pH} /$ lead concentration interaction

\section{Discussion:-}

Both types of carbon have been characterized to appreciate their adsorption capacity. Indeed, a carbon is better than it has a low rate of ash and moisture and a large surface area (Gueu et al., 2006). In this study, the ash content is less than $3 \%$ and the moisture content does not exceed $8 \%$. As for the values of the adsorption capacity, they are above $400 \mathrm{mg} / \mathrm{g}$. These values, comparable to those obtained by Zeroual et al., (2011) and Mamane et al., (2016), indicate that the carbons obtained are of good quality.

The study of the adsorption kinetics gives an equilibrium time of 30 minutes and 10 minutes respectively for CAT1 and CAT2 with more than $80 \%$ removal of lead. The rapid adsorption observed during the first few moments may be due to the availability of active sites for the removal of lead (Khattria et al., 2009; Bouhamed et al., 2013). The difference in adsorption rate (after $10 \mathrm{~min}$, for example, 85.81\% of lead adsorbed on CAT1 and 79.17\% on CAT2) at this phase, could be related to the nature of the pores at the surface of the activated carbon. It could therefore be deduced that the carbonization temperature has an influence on the development of the porosity on the surface of the carbon. According to Mohanty et al., (2005), when temperature reaches the value of $600^{\circ} \mathrm{C}$, a restructuring takes place causing a decrease in the adsorption capacity of the activated carbon. These authors emphasize that at these temperatures the micropores are destroyed in the profile of macropores.

The optimization of the operating conditions for removing lead from water led to the choice of an experimental domain with the three study factors. In this field, the tests carried out give adsorption rates of between $87 \%$ and $96 \%$ thus showing the relevance of this choice. Table 4 and figure 2 also show that two of the three factors have a significant influence on the rate of removal of lead by prepared coals. This is the $\mathrm{pH}\left(\right.$ Variable $\left.\mathrm{X}_{2}\right)$ and the lead concentration (variable $\mathrm{X}_{3}$ ). In addition, interactions between carbons type (Variable $\mathrm{X}_{1}$ ) and concentration $\left(\right.$ Variable $\mathrm{X}_{3}$ ) and that between $\mathrm{pH}\left(\right.$ Variable $\mathrm{X}_{2}$ ) and concentration (Variable $\mathrm{X}_{3}$ ) significantly influence adsorption. Indeed, the absolute value of the $\mathrm{pH}$ and lead concentration coefficients and those of the interactions is greater than twice the standard deviation (Assidjo et al., 2005). In the predefined experimental field, the equation of the adsorption rate $(\mathrm{Y})$ of lead as a function of the different parameters is thus given by the following mathematical model. 


\section{$Y=90,548+1,188 X_{2}+0,875 X_{3}+2,325 X_{2} X_{3}-0,680 X_{1} X_{3}$}

Detailed study of the different coefficients of factors having a significant influence on lead adsorption makes it possible to understand the effect of these and their interactions. Thus, for $\mathrm{pH}$, when the value goes from 3 to 6 , the adsorption capacity of lead increases $2.38 \%$ (value of $\mathrm{b} 2=1.188$ ). From this it can be deduced that a rise in $\mathrm{pH}$ in an acidic medium causes a rise in the rate of adsorption of lead. These results are consistent with those obtained by (Hamane et Bendjama., 2005; Arris, 2008; Boudrahem et al., 2011). The latter studied the adsorption of Pb2+ ions on materials derived from biomass. For these authors, this increase could be explained by the fact that in acidic medium there is production of $\mathrm{H}^{+}$ions which would make the adsorption of $\mathrm{Pb}_{2}{ }^{+}$ions less favorable. The increase of the $\mathrm{pH}$ which indicates the decrease of the protons, thus releases the sites of adsorption of the coal thus rendering them more available for the adsorption of $\mathrm{Pb}_{2}{ }^{+}$ions. The maximum fixation of these is obtained at a $\mathrm{pH}$ equal to 6 . This observation was also noted for the adsorption of lead from river sediments on spruce sawdust (Marin et Ayele, 2002).

Regarding the influence of the initial concentration of lead, there is an average increase of $1.75 \%$ of the adsorption capacity when the concentration of lead increases from 30 to $150 \mathrm{mg} / \mathrm{L}$. An increase in the concentration therefore has a positive effect on the adsorption capacity. These results are supported by those of (Mouni et al., 2014) who worked on the removal of $\mathrm{Pb}_{2}{ }^{+}$ions by adsorption on activated carbons prepared and encapsulated in a closed stirred reactor. For these authors, the increase in the quantity adsorbed with the concentration can be explained by a great variability of the adsorption sites and the presence surface. Thus, the transfer of the solute would be all the better that the concentration of the solutions is high. Knappe et al., (1998) have achieved the same result and claim that the higher the concentration, the higher the adsorption.

The results of the typical interaction-concentration interaction indicate that when the concentration goes from $30 \mathrm{mg}$ / L to $150 \mathrm{mg}$ / $\mathrm{L}$, the average lead absorption rate increases from $89 \%$ to $92 \%$ for CAT 1 carbon. On the other hand, for the same variation in the concentration of lead, the adsorption rate remains unchanged in the case of CAT2 carbon. In this area, the effect of lead concentration depends on the type of carbon. The best lead adsorption rate is reached at the maximum value of the concentration $(150 \mathrm{mg} / \mathrm{L})$ with the CAT1 carbon. These results show that increasing the concentration of lead improves the lead adsorption rate with CAT1.

Concerning $\mathrm{pH}$ and concentration interaction, we notice an increase of $7.03 \%$ when the $\mathrm{pH}$ goes from 3 to 6 and that the concentration is at its high level $(150 \mathrm{mg} / \mathrm{L})$. However, when the concentration of lead is low $(30 \mathrm{mg} / \mathrm{L})$, the adsorption rate is reduced by $2.28 \%$ for the same $\mathrm{pH}$ change. In this field, the effect of the lead concentration on the adsorption rate depends on the level of the $\mathrm{pH}$ factor. Finally, the optimal conditions for lead adsorption, in the experimental field, are obtained with $0.3 \mathrm{~g}$ of carbon, at $\mathrm{pH} 6$ and at a temperature of $25^{\circ} \mathrm{C}$. Under these conditions, for $150 \mathrm{mg} / \mathrm{L}$ of lead, after 30 minutes, an adsorption rate of $96 \%$ is obtained.

\section{Conclusion:-}

This work is based on the use of experimental designs to optimize the operating conditions for the elimination of lead by activated carbons. The carbon used was obtained by the chemical preparation process, from coconut shells abundantly available in Côte d'Ivoire. The complete two-variable factorial design technique determined the effect of three factors and their interactions on lead adsorption. It should be noted that lead adsorption depends on the $\mathrm{pH}$ and concentration of the pollutant and their interactions. A removal rate of nearly $95 \%$ is obtained for a concentration of $150 \mathrm{mg} / \mathrm{L}$ at $\mathrm{pH}=6$. It is therefore possible to optimize, using mathematical tools, the operating conditions for the purification of wastewater using the activated carbon adsorption process from agricultural waste.

\section{Reference:-}

1. Demim S., Drouiche N., Aouabed A., Benayad T., Dendene-Badache O. and Semsari S. (2013): Cadmium and nickel: assessment of the physiological effects and heavy metal removal using a response surface approach by L. Gibba. Ecological Engineering. 61: 426-435.

2. Song X. L., Liu H. Y., Cheng L., and Qu Y. X. (2010): Surface modification of coconut-based activated carbon by liquid-phase oxidation and its effects on lead ion adsorption. Desalination. 255: 78-83.

3. Yobouet Y. A., Aboua K. N., Adoubi K. et Yao K. B. (2018): Élimination du plomb et du cuivre en solution aqueuse par des charbons à base de bois de Pterygota macrocarpa. Afrique Science. 14 (2) : 38- 47. 
4. Gbamele K. S., Atheba G. P., Dongui B. K., Drogui P., Robert D., Kra O. D., Konan S., De Bouanzi G. G. M. et Trokourey A. 2016. Contribution à l'étude de quatre charbons activés à partir des coques de noix de coco. Afrique Science. 12(5) : 229-245.

5. Murat M. N., Ahmad M. A. and Idris M. N. 2018. Optimization of preparation conditions for rice husk based activatedcarbons for the removal of methylene blue dye. International Journal of Petrochemistry and Research. 2(2) : 186-188.

6. Tchakala I. , Bawa L. M., Djaneye-Boundjou G., Doni K. S. et Nambo P. (2012): Optimisation du procédé de préparation des Charbons Actifs par voie chimique (H3PO4) à partir des tourteaux de Karité et des tourteaux de Coton. International Journal of Biological and Chemical Sciences. 6(1) : 461-478.

7. Aboua K. N., Yao K. B., Gueu S. and Trokourey A. (2010): Production of activated carbon from biomass resources - optimization using experimental designs. Research Journal of Biological Sciences. 6(6): 665-670.

8. Me Convey I. F. and Me Kay G. (1985): Mass transfer model for the adsorption of basic dyes on woodmeal in agitated batch adsorbers. Chemical Engineering and Processing. 19: 267-275.

9. Mazet M. , Dusart O., Roger M. et Dussoubs-Marmier D. (1990): Elimination de colorants de l'industrie textile par des sciures de bois. Journal of Water Science. 3: 129-149.

10. Gueye M. (2015): Développement de charbon actif à partir de biomasses lignocellulosiques pour des applications dans le traitement de l'eau', Thèse de l'Institut International de l'Ingénierie de l'Eau et l'Environnement (2IE), Ouagadougou, Burkina Faso. 215p.

11. Maazou S. D. B., Hima H. I., Malam Alma M. M., Adamou Z. et Natatou I. (2017): Elimination du chrome par du charbon actif élaboré et caractérisé à partir de la coque du noyau de Balanites Aegyptiaca. International Journal of Biological and Chemical Sciences. 6(1) : 3050-3065.

12. Avom J., Ketcha M. J., Matip M. R. L. and Germain P. (2001): Adsorption isotherme de l'acide acétique par des charbons d'origines végétale. African Journal of Science and Technology (AJST). Science and engineering Series. 2(2) : 1-7.

13. Feinberg M. (1996): La validation des Méthodes d'Analyse : Une Approche Chimiométrique de l'assurance qualité au laboratoire. Masson, Paris, France. 217-239.

14. Massart D. L., Vandeginste B. G. M., Deming S. N., Michotte Y. and Kaufman L. (1988): Chimiometrics : A Texbook. Elsevier, Amsterdam, Holland. 2(4): 298-299.

15. Mathieu D., J. Nony et R. Phan-Tan-Luu, '’Nemrod-W : Génération des matrices d'expériences en fonction des objectifs et traitement des réponses expérimentales', Version 9901.

16. Choumane F. Z. (2016): Elimination des métaux lourds et pesticides en solution aqueuse par des matrices argileuses. Thèse de doctorat de Université Abou Bekr Belkaid, Tlemcen, République Algérienne Démocratique et Populaire. $187 \mathrm{p}$.

17. Depci T., Kul R. A. and Önal Y. (2012): Competitive Adsorption of Lead and Zinc from Aqueous Solution on Activated Carbon Prepared from Van Apple Pulp: Study in Single- and Multi-Solute Systems. Chemical Engineering Journal. Vol. 200-202, pp. 224-236.

18. Gueu S., Yao K. B., Adouby K. et Ado G. (2006): Elimination des métaux lourds des eaux avec le charbon actif préparé à partir de noix de coco et de graine de palmiste. 9èmes Journées Anuelles de la Société OuestAfricaine de Chimie, Dakar, Sénégal.

19. Zeroual S., Guerfi K., Hazourli S. et Charnay C. (2011): Estimation de l'hétérogénéité d'un charbon actif oxydé à différentes températures à partir de l'adsorption des molécules sondes. Revue des Energies Renouvelables. 14 (4) : 581-590.

20. Mamane S. O., Zanguina A., Daou I. et Natatou I. (2016): Préparation et caractérisation de charbons actifs à base de coques de noyaux de Balanites Eagyptiaca et de Zizyphus Mauritiana', Journal de la Société OuestAfricaine de Chimie. 041: 59- 67.

21. Khattria S. D. and Singh M. K. (2009): Removal of malachite green from dye wastewater using neem sawdust by adsorption. Journal of Hazardous Materials. 167: 1089-1094.

22. Bouhamed F., Elouear Z., Bouzid J. and Ouddane B. (2013): Batch sorption of Pb (II) ions from aqueous solutions using activated carbon prepared from date stones: equilibrium, kinetic, and thermodynamic studies. Desalination and Water Treatment. 52(10-12): 2261-2271.

23. Mohanty K., Das D., Biswas M. N. (2005): Adsorption of phenol from aqueous solutions using activated carbons prepared from Tectona grandis sawdust by ZnCl. Chemical Engineering Journal. 115: 121-131.

24. Assidjo E., Yao B., Akou E. and Ado G. (2005): Optimization of the treatment conditions of cocoa butter in order to reduce non-quality. J. Chemometrics. $19: 543-548$.

25. Hamane D. et Bendjama Z. (2005): Adsorption de Pb (II) par la Sciure de Bois d'Eucalyptus. Récents. Progrès en Génie des Procédés. 92. 
26. Arris S. (2008): Etude Expérimentale de l'Elimination des Polluants Organiques et Inorganiques par Adsorption sur des Sous-Produits de Céréales. Thèse de Doctorat, Faculté des Sciences de l'Ingénieur. Constantine, Algérie, 151p.

27. Boudrahem F., Aissani-Benissad F. and Soualah A. (2011): Adsorption of Lead (II) from Aqueous Solution by Using Leaves of Date Trees As an Adsorbent. Journal of Chemical and Engineering Data. 56: 1804-1812.

28. Marin J. et Ayele J. (2002): Removal of some heavy metal cations from aqueous solutions by spruce sawdust. I. Study of the binding mechanism through batch experiments', Environmental Technology. 23: 1157-1171.

29. Mouni L., Belkhiri L., Zouggaghe F. and Tafer M. (2014): Removal of Pb (II) from aqueous solution by adsorption using activated carbon developed from Apricot stone: equilibrium and kinetic. Desalination and Water Treatment. 52(34-36): 6412-6419.

30. Knappe D. R. U, Matsui Y. and Snoeyink V. L. (1998): Predicting the capacity of Powdered Activated Carbon for trace organic compounds in natural waters. Environmental science \& technology. 32(11): 16941698. 